\title{
HUBUNGAN PERLAKUAN BODY SHAMING DENGAN CITRA DIRI MAHASISWA
}

\author{
Rahmad Hidayat ${ }^{1}$, Eka Malfasari ${ }^{1}$, Rina Herniyanti ${ }^{1}$ \\ ${ }^{1}$ Program Studi S1 Keperawatan, Sekolah Tinggi Ilmu Kesehatan Payung Negeri Pekanbaru \\ mizzeka18@gmail.com
}

\begin{abstract}
ABSTRAK
Perlakuan body shaming adalah pengalaman yang di alami individu ketika kekurangan di pandang sebagai sesuatu yang negatif oleh orang lain dari bentuk tubuhnya.Efek dari perlakuan body shaming bisa membentuk citra diri positif ataukah negatif dari seorang tersebut..Tujuan penelitian ini untuk mengatahui hubungan perlakuan body shaming dengan citra diri pada mahasiswa STIKes Payung Negeri Pekanbaru. Jenis penelitian ini kuantitatif dengan desian penelitian korelasi dengan menggunakan pendekatan Cross- Sectional. Sampel penelititan teridiri dari 103 Mahasiswa. Metode pengambilan sample adalah purposive sampling. Penelitian ini dimulai tanggal 01-03 mei 2018. Analisis yang digunakan adalah uji statistik Chi-Square. Hasil uji statistik didapatkan nilai pvalue $=$ 0,036, hal ini berarti berarti nilai $\mathrm{p}<0,05$ sehingga Ho ditolak, artinya terdapat hubungan signifikan antara perlakuan body shaming dengan citra diri pada mahasiswa STIKes Payung Negeri Pekanbaru, dan nilai OR (Odds Ratio) sebesar 0,343 dengan CI (Confidence Interval) 0,136-0,865. Rekomendasi penelititan ini adalah memberikan intervensi untuk mengurangi perlakuan body shaming pada remaja untuk meningkatkan citra diri.
\end{abstract}

Kata kunci : Perlakuan body shaming, Citra diri.

\section{RELATIONSHIP BETWEEN BODY SHAMING TREATMENT WITH SELF-IMAGE STUDENTS}

\begin{abstract}
The treatment of body shaming is an experience experienced by the individual when deficiency is seen as something negative by others of his or her body shape. The effect of the body shaming treatment can form a positive self-image or negative of a person.. The purpose of this study to knowing relationship treatment of body shaming with self-image at STIKes Payung Negeri Pekanbaru students. This type of research was quantitative with the descriptions of correlation research using Cross-Sectional approach. The research sample consisted of 103 Students. with purposive sampling. Tehnique this research was started on 01-03 May 2018. The analysis used Chi-Square statistical test. The result of statistical test is $p$ value $=0.036$, it means $p$ value $<0,05$ so ho is rejected, it means there is a significant correlation between body shaming treatment with self image of STIKes Payung Negeri Pekanbaru student, and OR (Odds Ratio) value equal to 0.343 with CI (Confidence Interval) 0,136-0,865. This research recommendation is to provide intervention to reduce the body shaming treatment in adolescents to improve self-image.
\end{abstract}

Keywords: Body shaming treatment, Self image

\section{PENDAHULUAN}

Perlakuan body shaming adalah pengalaman yang di alami individu ketika kekurangan di pandang sebagai sesuatu yang negatif oleh orang lain dari bentuk tubuhnya. Perlakuanbody shaming termasuk bullying secara verbal dengan membully badan seseorang (Dolezal, 2015). Bukti yang menunjukkan pengalaman memalukan dahulu menjadi identitas diri dan di jadikan sebagai kenangan traumatis terkait dengan perasaan malu di masa depan serta meningkatkan kerentanan terhadap traumatis, traumatis termasuk salah satu efek dari perlakuan body shaming tersebut (Matos, 2013).

Efek dari perlakuan body shaming sangat banyak negatifnyahasil penelitian menunjukan bahwa perlakuan body shaming dapat bedampak pada pola pikir yang negatif pada 
seseorang. Hasilnya menunjukan bahwa perlakuan body shaming dapat menimbulkan penilaian diri sendiri yang buruk (Eva, 2016). Penelitian pada sampel wanita dengan gangguan makan memperoleh hasil yang menunjukan bahwa pengalaman malu sejak dini dikaitkan dengan tanda gangguan makan lebih parah karena efek dari rasa malu yang sangat tinggi terutama citra tubuh. Efek dari rasa malu pada tubuh dapat memberi efek negatif sehingga cenderung untuk mengikuti apa yang orang lain sampaikan terkait dengan kondisi tubuh, prilaku makan tidak teratur di pengaruhi oleh sejauhmana pengalaman rasa malu di alami sehingga menjadikan rasa tidak percaya diri, tidak menarik, tidak layak dalam kelompok sosial. Hasil penelitian ini menunjukan adanya hubungan antara pengalaman perlakuan body shaming terhadap wanita dengan gangguan makan. Pada wanita dengan gangguan makan, pengalaman rasa malu dengan penampilan fisik tampaknya memegang peran dalam penelitian ini. Apalagi hasil penelitian ini menunjukan adanya perubahan fungsi kognitif tubuh yang signifikan (Duarte, 2017).

Hasil penelitian terdiri dari 114 wanita dengan diagnosis Binge Eating Disorder (BED) atau gangguan makan $78 \%$ peserta menjawab efek dari rasa malu pada tubuh dapat memberi efek negatif sehingga cenderung untuk mengikuti apa yang orang lain sampaikan terkait dengan kondisi tubuh, prilaku makan tidak teratur di pengaruhi oleh sejauhmana pengalaman rasa malu di alami sehingga menjadikan rasa tidak percaya diri, tidak menarik, tidak layak dalam kelompok sosial. Dan 22\% menjawab biasa-biasa saja ketika ada yang mengejek mereka dan menganggap itu sebagai motivasi bagi mereka untuk menjadikan tubuhnya menjadi lebih proporsional (Duarte, 2017).

Citra diri di sebut juga dengan gambaran diri, citra diri adalah sikap seseorang terhadap tubuhnya secara sadar dan tidak sadar. sikap ini mencakup persepsi dan perasaan tentang ukuran, bentuk, fungsi penampilan dan potensi tubuh saat ini dan masa lalu yang secara berkesinambungan di modifikasi dengan pengalaman baru setiap individu (Yusuf, 2015). Mahasiswa merasa tidak puas terhadap penampilan mereka di sebabkan karena adanya perubahan bentuk fisik yang sangat besar pada masa mahasiswa. Sejumlah peneliti berpendapat bahwa penampilan fisik sangat berpengaruh pada rasa percaya diri mahasiswa, bahwa penampilan fisik berkorelasi paling kuat dengan rasa percaya diri (Murasmutia, 2012).

Faktor-faktor yang mempengaruhi citra diri adalah penilaian atau komentar orang lain, perbandingan dengan orang lain, peran seseorang, identifikasi terhadap orang lain. Citra diri bisa tertanam pikiran bawah sadar oleh pengaruh orang lain, pengaruh lingkungan pengalaman masa lalu atau sengaja di tanamkan oleh pikiran bawah sadar. Citra diri ada yang bersifat positif dan ada juga yang bersifat negatif (Gunarsih, 2013).

Hasil wawancara pada mahasiswa STIkes Payung Negeri Pekanbaru dari 15 mahasiswa menunjukan sekitar 10 mahasiswa menjawab ketika seseorang melakukan perlakuan body shaming efeknya bisa merasa rendah diri, merasa banyak kekurangan, merasa malu, menjadi kurang percaya diri, merasa cemas. Dan 5 mahasiswa lagi menjawab biasa- biasa saja dan menganggap bahwa orang itu hanya bercanda. Berdasarkan uraian latar belakang tersebut penulis tertarik melakukan penelitian tentang body shaming dengan judul "Hubungan Perlakuan Body Shaming Dengan Citra DiriPada Mahasiswa STIKes Payung Negeri Pekanbaru". Tujuan dari penelitian ini adalah untuk mengetahui hubungan perlakuan body shaming dengan citra diri pada mahasiswa STIKes Payung Negeri Pekanbaru.

\section{METODE}

Jenis penelitian ini merupakan penelitian kuantitatif dengan desain penelitian yang digunakan adalah desain korelasi dengan menggunakan pendekatan studi cross sectional (Wibowo, 2014). Dalam penelitian ini, desain yang digunakan bertujuan untuk mengetahui hubungan perlakuan body shaming dengan citra diri. Teknik pengambilan sampling yang digunakan adalah purposive sampling. 
HASIL

Adapun hasil penelitian tentang hubungan perlakuan body shaming dengan citra diri disajikan pada tabel berikut:

Tabel 1.

Karakteristik responden $(\mathrm{n}=103)$

\begin{tabular}{lcc}
\hline \multicolumn{1}{c}{ Karakteristik } & $\mathrm{f}$ & $\%$ \\
\hline Umur & 102 & 99 \\
17-25 (Remaja akhir) & 1 & 1 \\
27(dewasa awal) & & \\
\hline Jenis kelamin & 37 & 35,9 \\
Laki-laki & 66 & 64,1 \\
Perempuan &
\end{tabular}

Tabel 1 menunjukkan bahwa mayoritas responden berusia 17-25 tahun dan berjenis kelamin perempuan.

Tabel 2.

IMT responden $(\mathrm{n}=103)$

\begin{tabular}{lcc}
\hline \multicolumn{1}{c}{ IMT } & f & $\%$ \\
\hline Underwight & 57 & 55,3 \\
Overwight & 46 & 44,7 \\
\hline
\end{tabular}

Tabel 2 menunjukkan bawa IMT responden mayoritas underweight.

Tabel 3.

Perlakuan body shaming mahasiswa $(\mathrm{n}=103)$

\begin{tabular}{lcc}
\hline \multicolumn{1}{c}{ body shaming } & f & $\%$ \\
\hline Baik & 50 & 48,5 \\
Buruk & 53 & 51,5 \\
\hline
\end{tabular}

Tabel 3 menunjukkan bahwa mayoritas perlakuan body shaming mahasiswa mempunyai perilaku buruk.

Tabel 4.

Perlakuan citra diri mahasiswa $(\mathrm{n}=103)$

\begin{tabular}{|c|c|c|}
\hline Citra diri & f & $\%$ \\
\hline Positif & 43 & 41,7 \\
\hline Negatif & 60 & 58,3 \\
\hline
\end{tabular}

Tabel 4 menunjukkan bahwa mayoritas citra diri mahasiswa berada pada citra diri negatif.

Tabel 5.

Hubungan perlakuan body shaming dengan citra diri mahasiswa $(\mathrm{n}=103)$

\begin{tabular}{|c|c|c|c|c|c|c|}
\hline \multirow{3}{*}{$\begin{array}{l}\text { Perlakuan body } \\
\text { shaming }\end{array}$} & \multicolumn{4}{|c|}{ Citra diri } & \multirow[t]{2}{*}{$\mathrm{OR} / \mathrm{CI}$} & \multirow[t]{2}{*}{$P$ value } \\
\hline & \multicolumn{2}{|c|}{ Positif } & \multicolumn{2}{|c|}{ Negatif } & & \\
\hline & $\mathrm{f}$ & $\%$ & $f$ & $\%$ & 0,383 & 0,032 \\
\hline Baik & 15 & 30 & 35 & 70 & $(0,170-0,860)$ & \\
\hline Buruk & 28 & 52,8 & 25 & 47,2 & & \\
\hline
\end{tabular}

\section{PEMBAHASAN}

Usia

Berdasarkan tabel 1 didapatkan mayoritas responden yang mendapat perlakuan body shaming adalah 21 tahun emosi remaja masih labil. Perubahan sosial yang terjadi, yaitu remaja akan lebih dekat dengan teman sebayanya dan memisahkan diri dari orang tua dengan maksud menemukan jati diri, remaja membentuk kelompok dan mengekspresikan segala potensi yang dimiliki. Pada masa remaja cenderung ingin mencoba hal-hal baru, baik hal positif maupun hal negatif, hal negatif salah satunya adalah kenakalan remaja. 
Menurut asumsi peneliti,usia remaja pada saat ini merupakan usia dimana remaja mulai berpikir tentang bentuk tubuhnya dan bagaimana cara dia mengatasi perubahan tersebut dan melihat dari bentuk tubuh orang lain, artis ataupun teman-temanya yang lain dan disitulah menimbulkan perlakuan body shaming dari melihat bentuk tubuh temanya yang kurus ataupun yang gendut.

\section{Jenis kelamin}

Gambaran karakteristik responden tentang jenis kelamin pada penelitian ini diketahui bahwa sebagian besar responden berjenis kelamin perempuan 66 responden $(64,1 \%)$ sedangkan sisanya 37 responden $(35,9 \%)$ berjenis kelamin laki-laki. Dari hasil penelitian ini perempuan lebih banyak mendapatkan perlakuan body shaming, Perlakuan body shaming ini berkembang dan berfungsi bukan hanya sebagai emosi melainkan berupa penilaian diri yang dapat muncul karena ada ketidakpuasan atas apa yang dimiliki dalam individu. Perlakuan body shaming lebih sering dialami oleh wanita, Hal ini terjadi karena wanita lebih mudah menghayati penilaian subyektif dibandingkan laki-laki (Marta, 2016).

Seorang wanita akan semakin tidak menyukai ukuran tubuhnya sendiri ketika ukuran tersebut semakin jauh dari yang ideal. Semakin mendekati kecocokan diantara citra diri yang ada dan yang ideal yang dipegang oleh individu, maka akan semakin besar kemungkinan orang tersebut akan menunjukkan secara umum perasaan, harga diri yang dengan begitu pula akan merasa positif. Apabila terjadi kesenjangan yang terlalu jauh antara tubuh yang dipersepsi dengan gambaran ideal yang dipegang individu maka akan menyebabkan penilaian yang negatif terhadap tubuhnya sehingga citra dirinya menjadi negatif. Penilaian negatif tersebut yang membuat sesorang tidak dapat menerima kondisi tubuhnya secara apa adanya. Ketidaksesuaian antara tubuh yang dipersepsi dengan gambaran tubuh idealnya 101 akan memunculkan ketidakpuasan terhadap tubuhnya yang akan mendorongnya untuk merubah penampilan, salah satunya dengan melakukan diet(Husna, 2013).
Menurut asumsi peneliti, jenis kelamin juga mempengaruhi perlakuan body shaming. Dalam hal ini perempuan cenderung mengalami perlakuan body shaming karena perempuan lebih kuat tersinggungnya dari pada laki-laki, pada perempuan lebih memikirkan bagaimana cara mengatasi perubahan bentuk tubuh yang mereka alami dan bagaimana penampilan mereka berbeda dengan remaja laki-laki yang tidak terlalu mengkhawatirkan penampilan mereka.

\section{IMT (Indeks Massa Tubuh)}

Gambaran karatkeristik responden tentang IMT pada penelitian ini diketahui bahwa sebagian besar responden memiliki tubuh yang underwight 57 responden (55,3\%). Dan yang bertubuh overwight 46 responden (44,7\%). Mahasiswi yang merasa dirinya terlalu kurus, menjadi kurang percaya diri karena kurangnya lemak telah membuat tulang-tulang mereka menjadi nampak sangat menonjol seperti orang menderita kekurangan gizi, mereka berusaha menggunakan pakaian yang dapat membuat tubuh mereka nampak lebih berisi dan berlekuk, serta menyembunyikan tulang-tulang yang nampak menonjol. Padahal, sebenarnya mereka ingin menggunakan berbagai macam model pakaian dan tidak perlu khawatir akan terlihat jelek atau aneh ketika sedang memakaianya. Berbicara tentang pendapat orang lain, memang inilah yang menjadi faktor pemicu utama mengapa para mahasiswi ingin mempunyai tubuh yang ideal. Pikiran, pendapat, dan perlakuan dari orang lain terhadap diri mereka mempengaruhi penilaian mereka terhadap diri sendiri. Contohnya, ada seorang mahasiswi yang mengaku bahwa sebenarnya dia merasa nyaman dengan tubuh kurusnya. akan tetapi, karena keluarga dan teman-temanya sering mengatakan bahwa dia terlalu kurus, ceking, seperti kekurangan gizi, ringkih, dan sejenisnya, dia pun merasa bahwa ada sesuatu yang salah dengan tubuhnya. Oleh karena itu, dia lantas ingin menaikan berat badanya, membuat tubuhnya terlihat lebih berisi (Bestiana, 2012). Menurut asumsi peneliti, IMT mempengaruhi perlakuan body shaming seseorang yang bertubuh kurus lebih sering dihina karena tubuhnya yang kurus dibandingkan seseorang yang bertubuh gemuk yang di anggap lebih berisi. 


\section{Perlakuan body shaming}

Tabel 3 hasil peneletian menunjukan sebagian besar responden terdapat 53 responden $(51,5 \%)$ yang mendapat perlakuan body shaming yang buruk dan terdapat 50 responden $(48,5 \%)$ yang mendapat perlakuan body shaming yang baik. Efek dari rasa malu pada tubuh dapat memberi efek negatif sehingga cenderung untuk mengikuti apa yang orang lain sampaikan terkait dengan kondisi tubuh, prilaku makan tidak teratur di pengaruhi oleh sejauhmana pengalaman rasa malu di alami sehingga menjadikan rasa tidak percaya diri, tidak menarik, tidak layak dalam kelompok sosial. Hasil penelitian ini menunjukan adanya hubungan antara pengalaman perlakuan body shaming terhadap wanita dengan gangguan makan. Pada wanita dengan gangguan makan, pengalaman rasa malu dengan penampilan fisik tampaknya memegang peran dalam penelitian ini. Apalagi hasil penelitian ini menunjukan adanya perubahan fungsi kognitif tubuh yang signifikan, Efek dari rasa malu pada tubuh dapat memberi efek negatif sehingga cenderung untuk mengikuti apa yang orang lain sampaikan terkait dengan kondisi tubuh, prilaku makan tidak teratur di pengaruhi oleh sejauhmana pengalaman rasa malu di alami sehingga menjadikan rasa tidak percaya diri, tidak menarik, tidak layak dalam kelompok sosial (Duarte, 2017).

Efek dari perlakuan body shaming sangat banyak negatifnyahasil penelitian menunjukan bahwa perlakuan body shaming dapat bedampak pada pola pikir yang negatif pada seseorang. Hasilnya menunjukan bahwa perlakuan body shaming dapat menimbulkan penilaian diri sendiri yang buruk (Eva, 2016). Berdasarkan hasil dari keusioner perlakuan body shaming dari 15 pertanyaan didapatkan nilai yang tertinggi adalah pertanyaan nomor 5 pertanyaan tersebut menggunakan pernyataan favorable (positif) dan unfavorable (negatif). Pertanyaan no 5 adalah saya tidak mau makan ketika seseorang menghina saya gendut/kurus mayoritas responden menjawab kadangkadang berarti dapat disimpulkan bahwa seseorang yang mendapat perlakuan body shaming dapat mempengaruhi terhadap menurunya nafsu terhadap makanan. Dengan kategori baik dan buruk mayoritas responden memiliki perlakuan body shaming yang buruksebanyak 53 responden.

Menurut asumsi peneliti seseorang yangmendapat perlakuan body shaming lebih banyak yang mengarah yang buruk. Perlakuan body shaming merupakan pengalaman emosi yang dialami individu ketika individu tersebut merasa bahwa yang dilakukannya tidak sesuai dengan yang diharapkan diri sendiri maupun lingkungan dan individu tersebut menganggap bahwa orang lain mengetahui keadaan itu. Sehingga membuat menyebabkan rasa tidak percaya diri, menyebabkan rasa malu, ketidakpuasan terhadap tubuhnya sendiri. Walaupun ada sisi baiknya dari perlakuan body shaming yaitu menyebabkan rasa ingin memperbaiki tubuhnya lagi. Tetapi perlakuan body shaming ini tetap sesuatu tindakan yang tidak baik.

\section{Citra diri}

Tabel 4 hasil penelitian menunjukan sebagian besar responden memilik citra diri negatif terdapat 60 responden $(58,3 \%)$ yang memiliki citra diri yang negatif dan terdapat 43 responden $(41,7 \%)$ yang memiliki citra diri yang positif.Hal ini sejalan dengan penelitian semakin tinggi kepercayaan diri maka semakin tinggi pula citra diri pada remaja, sebaliknya semakin rendah kepercayaan diri, maka semakin rendah pula citra diri pada remaja akhir. Adanya hubungan antara kepercayaan diri dengan citra diri pada remaja akhir, menunjukkan bahwa kepercayaan diri mempunyai pengaruh dalam citra diri pada remaja akhir. artinya menunjukkan bahwa terdapat korelasi positif yang signifikan antara kepercayaan diri dengan citra diri, sehingga. Artinya semakin tinggi tingkat kepercayaan diri maka semakin tinggi tingkat citra diri pada remaja akhir, sebaliknya semakin rendah tingkat kepercayaan diri maka semakin rendah pula tingkat citra diri pada remaja (Ramadhani, 2014).

Citra diri merupakan salah satu kategori penting dalam pertumbuhan remaja, karena pada masa remaja banyak perubahan yang akan terjadi pada remaja itu sendiri sehingga mereka mulai memikirkan bagaimana cara untuk memilki penampilan tubuh yang bagus 
dan mengejar kecantikan fisik menurut mereka itu sangat penting untuk masa depan mereka (Bragina, 2015).

Citra diri seseorang itu dapat dilihat dari evaluasi dari penampilan dan keseluruhan tubuh, apakah menarik atau tidak menarik serta memuaskan atau tidak memuaskan. Selain itu dapat dilihat melalui orientasi penampilan yaitu perhatian individu terhadap penampilan dirinya dan usaha yang dilakukan utnuk memperbaiki dan meningkatkan penampilan dirinya (Ithut, 2013).

Faktor yang memengaruhi citra diri adalah kepercayaan diri yaitu perasaan positif pada diri seseorang, merasa yakin bahwa pribadi tersebut berharga dan unik. Hal tersebut menunjukkan bahwa kepercayaan diri berhubungan dengan citra diri (Suryani, 2009). Berdasarkan hasil dari keusioner perlakuan body shaming dari 27 pertanyaan didapatkan nilai yang tertinggi adalah pertanyaan nomor 1 pertanyaan tersebut menggunakan pernyataan favorable (positif) dan unfavorable (negatif). Pertanyaan nomor 1 adalah saya sangat khawatir dengan apa yang orang lain pikirkan mengenai penampilan saya, mayoritas responden menjawab tidak setuju. Dengan kategori positif dan negatif mayoritas responden memiliki citra diri yang negatif sebanyak 60 responden.Menurut asumsi peneliti, perlakuan body shaming yang buruk mempengaruhi citra diri negatif pada remaja, membuat seseorang yang mengalami hilang nya percaya diri dan membuat mempengaruhi persepsi remaja tentang citra diri mereka.

\section{Analisis bivariat}

Hubungan perlakuan body shaming dengan citra diri pada mahasiswa STIKes Payung Negeri Pekanbaru menggunakan uji statistik "Chi Square" didapatkan hasil bahwa nilai $p$ value $(0,036)<\alpha(0,05)$, artinya hasil penelitian ini adalah ada hubungan perlakuan body shaming dengan citra diri pada mahasiswa STIKes Payung Negeri Pekanbaru dengan nilai OR 0,343 didapatkan bahwa responden yang mendapat perlakuan body shaming buruk memiliki citra diri negatif 0,343 kali dibandingkan dengan responden yang mengalami perlakuan body shaming yang baik. Hal ini sejalan dengan penelitian (Marta,
2016) tentang perlakuan body shaming merupakan pengalaman emosi yang dialami individu ketika individu tersebut merasa bahwa yang dilakukannya tidak sesuai dengan yang diharapkan diri sendiri maupun lingkungan dan individu tersebut menganggap bahwa orang lain mengetahui keadaan itu. Perlakuan body shaming ini berkembang dan berfungsi bukan hanya sebagai emosi melainkan berupa penilaian diri yang dapat muncul karena ada ketidakpuasan atas apa yang dimiliki dalam individu. Perlakuan body shaming dalam penelitian ini dapat mempengaruhi citra tubuh yang negatif dari rasa malunya tersebut menjadikan seseorang yang mengalami body shaming gangguan makan, menghargai terhadap tubuhnya sendiri berkurang, seorang yang mengalami perlakuan body shaming faktor utamanya mereka terlalu memasukan ke perasaanya kata-kata orang lain atau temantemanya sehingga menyebabkan citra tubuhnya negatif, kalau seorang tersebut citra tubuhnya positif bisa menganggap hinaan dari orangorang tersebut hanya candaan. Dalam penelitian ini juga cara menyembuhkan citra tubuh yang negatif yaitu dengan kasih sayang orang terdekat.

Hasil penelitian menunjukan bahwa perlakuan body shaming dapat menimbulkan penilaian diri sendiri yang buruk. Penelitian Apakah body shamingmempengaruhi kesehatan fisik yang buruk dan apakah ada perbedaan jender. Hasilnya perempuan lebih sering mendapat perlakuan body shaming dan perempuan mendapat perlakuan body shaming ini juga mempegaruhi kesehatan fisiknya. Efek dari perlakuan body shaming sangat banyak negatifnya bahwa body shaming dapat bedampak pada pola pikir yang negatif pada seseorang sehingga berefek pada kesehatan fisiknya (Eva,

2016).

Pada citra diri terdapat beberapa kategori yang mempengaruhi bagaimana seorang remaja memandang citra dirinya seperti appearance evaluation (evaluasi penampilan) yaitu bagaimana individu mengevaluasi penampilan dirinya apakah menarik atau tidak, appearance orientation (orientasi penampilan) yaitu perhatian individu terhadap dirinya dan usaha yang dilakukan untuk memperbaiki, body area satisfaction (kepuasan terhadap bagian tubuh) 
yaitu bagaimana individu mengukur kepuasan terhadap bagian tubuh secara spesifik, overwight preoccupation (kecemasan menjadi gemuk) yaitu mengukur kecemasan individu terhadap kegemukan, dan self-classifeid weight (pengkategorian ukuran tubuh) yaitu bagaimana individu mempersepsikan nilai berat badanya (Cash, 2006).

Penelitian pada sampel wanita dengan gangguan makan memperoleh hasil yang menunjukan bahwa pengalaman malu sejak dini dikaitkan dengan tanda gangguan makan lebih parah karena efek dari rasa malu yang sangat tinggi terutama citra tubuh. Efek dari rasa malu pada tubuh dapat memberi efek negatif sehingga cenderung untuk mengikuti apa yang orang lain sampaikan terkait dengan kondisi tubuh, prilaku makan tidak teratur di pengaruhi oleh sejauhmana pengalaman rasa malu di alami sehingga menjadikan rasa tidak percaya diri, tidak menarik, tidak layak dalam kelompok sosial. Hasil penelitian ini menunjukan adanya hubungan antara pengalaman perlakuanbody shaming terhadap wanita dengan gangguan makan. Pada wanita dengan gangguan makan, pengalaman rasa malu dengan penampilan fisik tampaknya memegang peran dalam penelitian ini. Apalagi hasil penelitian ini menunjukan adanya perubahan fungsi kognitif tubuh yang signifikan (Duarte, 2017).

\section{SIMPULAN DAN SARAN \\ Simpulan}

Mahasiswa STIKes Payung Negeri yang menjadi responden yang ditentukan dari kriteria peneliti, menunjukan bahwa sebagian besar yang mendapat perlakuan body shaming citra dirinya negatif mereka menganggap seriusseseorang yang mengejek meraka gendut ataupun kurus sehingga mempengaruhi citra dirnya yang negatif menjadikan rasa tidak percaya diri, merasa malu, tidak mau makan.

\section{Saran}

Perlunya intervensi untuk mengurangi perlakuan body shaming pada remaja untuk meningkatkan citra diri.

\section{DAFTAR PUSTAKA}

Batubara, J. R. L. (2010). Adolescent Development (Perkembangan Remaja). Sari Pediatri, 12(1), 21-29.
Retrieved

fromhttp://saripediatri.idai.or.id/pdfile /12-1-5.pdf

Bestiana, D. (2012). Citra Tubuh dan Konsep Tubuh Ideal Mahasiswi FISIP Universitas Airlangga Surabaya, 1(1). 1-12.

Bragina, I. V. (2015). Body Image And The Future Time Perspective Of Russian Adolescents. Procedia - Social and Behavioral Sciences, 191, 378-382. https://doi.org/10.1016/j.sbspro.2015. $\underline{04.153}$

Cash, T. F. \& P. (2006). Body Image A Handbook Of Theory, Reseaech \& Clinical Practice. London: The Guilford Press.

Dolezal. (2015). The Body and Shame: Phenomenology, Feminism, and the Socially Shaped Body'. Retrieved from

http://centreformedicalhumanities.org/ the-body-and-shame-phenomenologyfeminism-and-the-socially-shapedbody-reviewed-by-dr-emily-cock/

Duarte. (2017). The impact of early shame memories in Binge Eating Disorder: The mediator effect of current body image shame and cognitive fusion. Psychiatry Research, 258(June), 511517.https://doi.org/10.1016/j.psychres. 2017.08.086

Eva, L. (2016). Is body shaming predicting poor physical health and is there a gender difference? BSc in Psychology.

Gunarsih. (2013). hubungan konsep diri dengan strategi koping penderita stroke.

Husna, L. (2013). PERILAKU DIET ( Penelitian pada Wanita di Sanggar Senam RITA Pati ).

Ithut. (2013). Gambaran citra diri remaja yang mengalami overweight di smpn 1 bareng jombang. 
Marta, s. (2016). Eating Behaviors Exploring the effect of external shame on body appreciation among Portuguese young adults: The role of self-compassion. Eating Behaviors,23, 174-179.

https://doi.org/10.1016/j.eatbeh.2016. $\underline{10.006}$

Matos. (2013). Internalizing early memories of shame and lack of safeness and warmth: The mediating role of shame on depression. Behavioural and Cognitive Psychotherapy, 41(4), 479493.

https://doi.org/10.1017/S13524658120 $\underline{01099}$

Murasmutia. (2012). Hubungan Antara Citra Tubuh dan Kepercayaan Diri dengan Perilaku Konsumtif terhadap Pakaian pada Mahasiswi Fakultas Hukum Universitas Sebelas Maret Surakarta. Retrieved from candrajiwa.psikologi.fk.uns.ac.id/inde x.php/candrajiwa/article/download/11 $4 / 105$

Ramadhani. (2014). Hubungan antara kepercayaan diri dengan citra diri pada remaja akhir, 4(2), 22-32.

Suryani. (2009). Pelayanan Konseling pada Satuan Pendidikan Menengah. Jakarta: Grafindo Persada.

Yusuf. (2015). buku ajar keperawatan: kesehatan jiwa. Jakarta: salemba medika. 